\title{
The Validation of Badminton Textbook: Improving Students' Learning Outcomes
}

\author{
Novri Gazali", Romi Cendra \\ Department of Physical Education Health and Recreation, Universitas Islam Riau, Indonesia
}

Received March 2, 2020; Revised May 16, 2020; Accepted June 2, 2020

Copyright (C) 2020 by authors, all rights reserved. Authors agree that this article remains permanently open access under the terms of the Creative Commons Attribution License 4.0 International License

\begin{abstract}
The purpose of this study is to look for the validity of badminton textbooks for Physical Education and Recreational Education students. This type of research is research and development research. The study procedure uses development procedures according to Borg and Gall, namely: "(1) Research and information collecting, (2) planning, (3) developing preliminary forms of product, (4) preliminary field testing, (5) main product revision, (6) main field testing, operational product revision, (8) operational field testing, (9) final product revision, (10) dissemination and distribution. "In developing the research, it does not use entirely but only with 7 steps, namely 1) needs analysis, 2) makes products consisting of preparation of material preparation, instructional, books, and evaluation tools, 3) product validation consisting of media experts, learning experts, 4 ) small group trials using subjects 6-12 people, interview data, observations, and questionnaires are collected and analyzed, 5) revises phase I products, 6) large group trials using subjects 30-100. 7) phase II product revision. This textbook research used a questionnaire, namely (1) needs analysis questionnaire, (2) expert trials, (3) small groups, and (4) large groups. The conclusion of this study is that the validity score of this textbook is very high and this badminton textbook is very feasible to use because it has been validated by the material expert and instructor media.
\end{abstract}

Keywords Validation, Textbooks, Badminton, Learning Outcomes

\section{Introduction}

Textbooks and teaching and learning process have a very related relationship because they can complement each other. The teaching and learning process will be more effective if there are textbooks that are suitable with the material delivered by the instructor. Textbooks can be used and specifically designed for principles in learning. In textbook essences are the learning media of a particular discipline or knowledge (Kurniawan, 2010).

Books are generally seen as the main curriculum source in the classroom. Many studies discuss the importance of textbooks, Rezat (2012); Shield and Dole (2013); Polikoff (2015); Remillard, Harris, and Agodini (2014) mentioned in their researches that textbooks are important artifacts and the main source of providing educational opportunities. This textbook is an important teaching resource and appeals to many stakeholders, such as lecturers, teachers, students, students and parents. Robinson (2017) mentions in his book that the majority of students prefer information if it is presented in an interesting manner that is data dominated by a blend of images, graphics and colors.

Badminton courses are usually more dominant in learning movement skills, so some lecturers are not concerned with learning badminton in terms of cognitive. This will lead to the lack of knowledge that will be found by students. Therefore, in learning of badminton textbooks are needed so that students practice psychomotor more smoothly and the movements are correct. Therefore it is necessary to develop a textbook as a guide and also a lecturer's hand book to provide learning.

Based on observations on the implementation of badminton courses in the Department of Physical Education Health and Recreation at the Universitas Islam Riau that conducted by researchers, it is found several source of problems in learning badminton courses, namely: (1) students do not have badminton textbooks yet especially on badminton regulations and arbitration material, so that in the learning process especially learning badminton students have difficulty finding reference sources, (2) in cognitive learning students feel bored because they only get information from the lecturer so that it invites less enthusiasm on students.

Textbooks are very important teaching materials because they are used in teaching and learning activities, this is as a guide for teachers in providing learning. 
Textbooks are usually written and compiled by experts in related fields and meet the rules of textbooks and are published officially and distributed. According to Prastowo (2011) "textbooks are in general a teaching material produced by an author or team of authors which is compiled based on the curriculum or interpretation of the applicable curriculum". Meanwhile, according to Setiawan \& Sari (2018) "Textbooks are one of the results of the media in the form of print, as an opinion of an expert says, print media includes materials prepared on paper for teaching and information, including textbooks and textbooks ".

Based on the opinions of the experts above, it can be concluded that textbooks are concepts written and designed systematically by experts to be used as instructions and given to people or students as a guide and adapted to the teaching and learning process so that they are known and obeyed based on the curriculum. In the opinion of Hurd in Budiningsih., Rusilowati. \& Marwoto (2015) stressed that the low learning outcomes may be caused by the absence of textbooks used in the learning process. Therefore, a lecturer must have a textbook that can provide assistance for students in order to make it easier and to master the material that is both cognitive and psychomotor. So a lecturer must provide a textbook so that students are interested in reading the course learning they will teach.

The use of textbooks is indispensable in the learning process for teachers as educators and students as students. The advantages of textbooks according to Satrawijaya (1998) are as follows (a) textbooks contain a lot of information. (b) textbooks can be used individually. (c) textbooks can organize learning materials. (d) textbooks can be used to encourage students' motivation and thinking, (e) textbooks can help design learning, and (f) textbooks can help learning methodologies. Meanwhile, according to Prastowo (2011) (a) assists educators in implementing the curriculum because it is prepared based on the applicable curriculum, (b) becomes a guide in determining teaching methods, giving students the opportunity to repeat lessons or learn new lessons, provides knowledge for both students and educator. The purpose of this study was to develop a badminton textbook for students of the Department of Physical Education Health and Recreation at the Universitas Islam Riau.

Research and development in the field of education (R\&D) are a process used to develop and certify education products (Borg \& Gall, 1983). Borg and Gall (1983) state that the development research procedure basically consists of two main objectives, namely: (1) developing a product, and (2) testing the effectiveness of the product in achieving its objectives. The steps in this process are generally known as the R\&D cycle, which consists of: an assessment of the results of previous studies related to the validity of the components of the product to be developed, developing it into a product, testing of the product designed, and reviewing and correcting the product based on trial results.
This is an indication that the product of findings from the carried out development activities has objectivity (Borg \& Gall, 1983).

Borg and Gall (1983) proposed sequence of steps that should be reached in this approach, which are research and information collecting, planning, developing preliminary form of product, preliminary field testing, main product revision, main field testing, operational product revision, operational field testing, final product revision, and dissemination and implementation. Conceptually, the approach of research and developing includes 10 general steps as like they have been elaborated by Borg \& Gall (1983).

In developing this textbook product, the implementation phase is carried out by linguists, materials and the media by giving an assessment of the product in question form. In order the feasibility test by experts to be carried out in accordance with the objectives of development, the assessment is based on a reference to make learning resources adapted from the National Education Standards Agency (BSNP, 2014).

Data collection is used to obtain correct information, a researcher can increase the validity of the data collected (Mohajan, 2017). According to Azwar (2012), validity is the ability of a test to measure what must be measured. The purpose of building validity in research is to ensure that data is good and reproducible, and the results are accurate (Mohajan, 2017). Validity criteria involve correlations or relationships between measurement of interest and other instruments or standards that have been proven as accurate indicators of the same concept or construct being measured (DePoy\&Gitlin, 2016). DePoy and Gitlin (2016) stated in their book that instrument validation is very important to ensure, as far as possible, accuracy in measurement. In validating the research instrument, the questionnaire that used will be in line with previous research related to this research.

\section{Methodology}

\subsection{Types of Research}

This research uses research and development design. This research instrument is in the form of a questionnaire, namely (1) a needs analysis questionnaire, (2) expert trials, (3) small groups, and (4) large groups. The needs analysis questionnaire is given to students totaled 23 items consisting of (1) the existence of textbooks, (2) badminton course material, (3) presentation methods and (4) evaluation (Sainal, 2012). The expert validation sheet of learning material consists of 48 items, whose assessment indicators include (1) the accuracy and correctness of the material (the appropriateness of the contents), (2) the learning support material (the feasibility of the presentation), and (3) the language assessment 
(Rahmantiwi, 2012). While the media expert validation sheet and learning design consisting of 27 items, the assessment indicators include the feasibility of graphics consisting of (1) book size, (2) book cover design, and (3) book content design. Small group trials and large group trials which include: (1) Views, (2) Presentation of material, and (3) Benefits consisting of 30 items (Rahmantiwi, 2012).

\subsection{Research Locations}

The location of the study is the Department of Physical Education Health and Recreation, Universitas Islam Riau, Riau Province, Indonesia. The test subjects consist of: (1) Expert evaluation, namely 1 instructional media expert and 2 badminton subject learning experts. (2) Small group trials, use 6 Penjaskesrek students. (3) Large group trials, use 30 students of Physical Education Health and Recreation.

\subsection{Data Analysis}

Quantitative data analysis is done by means of data reproduction, data presentation, and drawing conclusions. While the validity criteria of the validator assessment questionnaire data can be viewed from the results of the percentage of criteria in table 1 .

Table 1. Validity of the Validation Assessment Questionnaire Data

\begin{tabular}{|c|c|}
\hline SkalaNilai(\%) & Validitas Level \\
\hline $85,01-100,00$ & $\begin{array}{l}\text { Very valid, can be used but needs a small } \\
\text { revision }\end{array}$ \\
\hline $70,01-85,00$ & Valid, can be used but needs a small revision \\
\hline $50,01-70,00$ & $\begin{array}{c}\text { Invalid, can be used but needs major } \\
\text { revision }\end{array}$ \\
\hline $01,00-50,00$ & Invalid, may not be used \\
\hline
\end{tabular}

(Akbar, 2013)

\section{Results}

\subsection{Description of Textbooks in Badminton}

The results of the validation of this textbook product are for students who will take part in lectures so that students have the handbook in doing the learning process.

\section{a. Product Identity}

On the badminton teaching product identity, the regulation and arbitration subject matter for the Department of Physical Education Health and Recreation students consist of:

$\begin{array}{ll}\text { Physical Form } & \text { Printed Material } \\ \text { Title } & \text { Buku Ajar Bulutangkis } \\ \text { Material } & \text { Badminton Course } \\ \text { Author } & \text { Novri Gazali, M.Pd } \\ & \text { Romi Cendra, M.Pd }\end{array}$
Print
First
Size
$15,5 \mathrm{~cm} \times 23 \mathrm{~cm}$

\section{b. Cover of Textbooks}

The cover of the badminton course textbooks covers the world badminton organization BWF and Indonesia PBSI, the title of the book and the background are adjusted to the contents of the badminton course such as pictures of shuttlecocks and recitals.

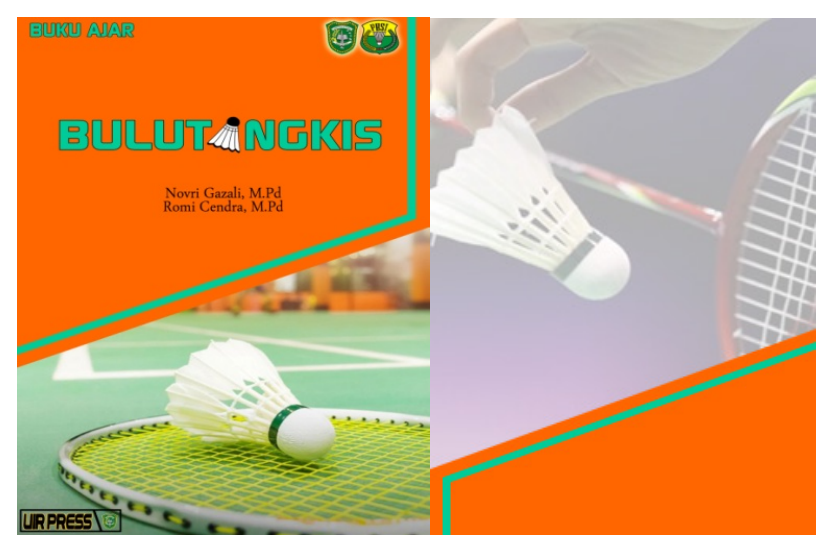

Figure 1. Front and Back Cover of the Book

\section{c. Foreword}

The preface is the opening point in this textbook because it is very important for the reader because it provides an overview and also communicates with the textbook author, this will give the impression that the textbooks that are prepared are very feasible and important to read and study, the superiority of textbooks with books that are others as well as related to the perfection of the textbook.

\section{d. Learning materials}

The learning material is adjusted to the learning material given by lecturers supporting badminton subjects.

\section{e. References}

Bibliography is a reference to the content of material from badminton learning obtained from sources such as book, articles and journals.

\subsection{Presentation of Textbook Product Validation Data}

The result of the validation of badminton textbooks for students of the Department of Physical Education Health and Recreation is a discussion on needs analysis, validation of learning material experts, validation of media and design experts, phase I (small group) trials, phase II trials ( large groups).

\subsection{Requirements Analysis}

The results of observations and interviews with the Head of the Department of Physical Education Health and Recreation are giving 8 questions. Namely: (1) Have 
lecturers ever developed course textbooks, if there is, mention / if there is no, give reason, (2) What is the view of the Head of the Study Program about lecturers who will conduct research on developing textbooks?, (3) Where is the source of the course material used by students? (4) How is the Head of Study Program's assessment of the textbooks used by students? (5) Are there obstacles from lecturers in finding suitable textbooks used in the learning process for students?, (6) Are there any obstacles encountered in the learning process?, (7) Are there plans in developing textbooks for all teaching lecturers?, (8) What is the view of the Chair of the Study Program about the reading interest of students in textbooks that have already been there?

Based on the needs analysis, it can be concluded that the need for badminton textbooks is very necessary because of the limited textbooks availability in the Department of Physical Education Health and Recreation in all courses. The students do not have adequate textbooks so that they have difficulty in obtaining or learning theories supporting the courses they follow. Therefore it must be maximized to produce textbook products because it is very helpful for lecturers and students in all learning materials in the courses they teach, specifically in badminton courses.

The results of observations on students use a questionnaire totaling 23 items consisting of (1) the existence of textbooks, (2) badminton course material, (3) presentation methods and (4) evaluation. Based on the results of the questionnaire given to students, $95.83 \%$ of students were happy with the learning process, $99.17 \%$ of students did not have badminton textbooks, $97.50 \%$ of students considered textbooks to be used, $100 \%$ of students strongly agreed to create Badminton textbooks in the lecture process, $97.50 \%$ need to provide variations on badminton course materials, $100 \%$ badminton textbooks need to be adjusted to the needs at the University, $95.83 \%$ badminton textbooks are very useful for students, evaluations that are badly presented in badminton lectures with $97 \%$ cognitive acquisition, $100 \%$ affective, $100 \%$ psychomotor, and $80 \%$ character, questions presented by lecturers when taking the exam with $100 \%$ description, the need to present homework assignments obtained $81.67 \%$, students agreed to make textbooks by lecturers of badminton courses with $100 \%$ gain, students who agreed to develop textbooks by lecturers in campus are charged with $100 \%$.

\section{a. Media and Design Expert Validation}

Validation of media and design experts is done by lecturers who have the capacity to assess media and textbook design in badminton courses. Based on the results of the validation of media and design experts with the acquisition of a minimum score of 27 , a maximum score of 108 , a score of 91 results with a percentage of $84.26 \%$ with a validity level that can be valid and can be used.

\section{b. Material Expert Validation}

The validation of the learning material expert was carried out by two lecturers of Physical Education Health and Recreation.The first expert is a lecturer at Universitas Riau who supports badminton courses and licensed by the National Badminton Referee and the second expert is a lecturer at Universitas Islam Riau who supports badminton courses.

Based on the results of the validation of learning material experts with aspects assessed namely (1) The accuracy of facts in the material (Feasibility of Content) with the acquisition of a minimum score of 42 , a maximum score of 168, a score of 133 results with a percentage of $79.17 \%$ with a validity level is Valid, can be used but needs a small revision, (2) Learning Support Materials (Presentation Feasibility) have a minimum score of 28, a maximum score of 112 , a score of 86 results with a percentage of $76.79 \%$ with a validity level is Valid, can be used but needs a small revision, and (3) Language Assessment has a minimum score of 26, a maximum score of 104 , a score of 82 results with a percentage of $78.27 \%$ with a validity level is Valid, can be used but needs a small revision. The overall validation result is $78.27 \%$ with the validity level is Valid and can be used but needs a small revision.

\section{c. Phase I Trial (Small Group)}

Phase I trials (small groups) of students in the Physical Education and Recreation Education Study Program were conducted with a total of 6 students. Based on the results of the validation of the phase I trial (small group) with the acquisition of a minimum score of 180 , a maximum score of 720 , a score of 630 results with a percentage of $87.5 \%$ with a level of validity is Very Valid and can be used.The results of the phase I trial can be seen in table 1 .

Table 1. Data on Phase I Trial Results (Small Group)

\begin{tabular}{cccccc}
\hline Component & Minimum Score & Maximum Score & Result Score & Percentage & Validity Level \\
\hline $\begin{array}{c}\text { Phase I Trial (Small } \\
\text { Group) }\end{array}$ & 180 & 720 & 630 & $87,5 \%$ & Very valid, can be used \\
\hline
\end{tabular}

Table 2. Data on Phase II Trial Results (Large Group)

\begin{tabular}{cccccc}
\hline Component & Minimum Score & Maximum Score & Result Score & Percentage & Validity Level \\
\hline $\begin{array}{c}\text { Phase II Trial } \\
\text { (Large Group) }\end{array}$ & 900 & 3600 & 3034 & $84,28 \%$ & Very valid, can be used \\
\hline
\end{tabular}




\section{b. Phase II Trial (Large Groups)}

Phase II trials (large groups) of students in the Physical and Recreational Education Study Program were conducted with a total of 30 students. In this trial, students were asked to look at the punctuation marks again. The use of letters in addition to the second phase of the trial was also asked to see the physical structure and shape of badminton textiles, the ease of product, the systematic presentation of the material and the benefits of the textbooks for student understanding. The results of the phase II trial can be seen in table 2 .

Based on table 2, it shows the result of validation of phase II trials (large groups) with the acquisition of a minimum score of 900 , a maximum score of 3034 , a score of 3034 results with a percentage of $87.5 \%$ with a level of validity is Very Valid and can be used.

\section{Discussion}

Based on the results of the research above, the development of badminton textbooks for students of the Physical Education and Recreation Education Study Program can be concluded that it is feasible to be used because it has been validated by material experts and media experts and learning badminton courses in accordance with comments and suggestions from the experts. According to Fidiastuti (2016), "the results of the development of products in the form of textbooks that have been revised based on comments and suggestions validator is aimed to to improve textbooks, so that the use of textbooks becomes more efficient, effective and communicative to the reader, with due regard to the objectives of the preparation of textbooks".

The main purpose of developing badminton textbooks is due to the lack of availability of textbooks in the Department of Physical Education Health and Recreation Therefore students are expected to be able to read, to study and to apply badminton theory and practice through this textbook. The process of developing badminton textbooks has been adjusted to the curriculum in the Health and Recreation Physical Education Study Program and the achievements of study programs and the achievement of badminton courses. The material is based on the Semester Learning Plan (RPS) of badminton courses and based on the study material that follows the indicators that have been made. This textbook has enough sources such as badminton books, journals, articles, and so forth. According to Husamah., Rochman. \& Sutomo (2016), "Information is then packaged according to the needs of students, then arranged, packaged, and written as teaching materials using a systematic framework".

The preparation of this textbook material has been adjusted for students. It aims to make students understand the theory and practice of badminton so that students can apply it when teaching process or practicing badminton. Therefore the material is very easy for students to understand, this is in line according to Abidin (2014) stating "Material must not be too little and should not be too much. If it is too little then it does not help to achieve competence and if it is too much it is not effective".

The results of research relate to the study of Lufthansa, Susilo, Zaini, Kusmawati, Pawitra. \& Anugraini (2019). Whereas Surahman, \& Yeni (2019) developed good and feasible textbooks which can be used after revisions in accordance with the advice and comments of material experts and media and design experts.

\section{Conclusions and Suggestions}

Based on the results of this study, it can be concluded that the validity score of this textbook is very high and very feasible to use because it has been validated by the material experts and instructional media experts. The development of textbooks for learning badminton courses can assist students get more leverage in the learning process of badminton courses and help to facilitate the task of educators. The produced products are products aimed on students of the Department of Physical Education Health and Recreation at the Universitas Islam Riau.

Researcher's suggestions in the development of the study go further, as follows (1) the subject of the study is expected to be wider, both from the number and or not only in students of the Physical Education and Recreation Education Study Program at the Universitas Islam Riau, but also it can be done at other tertiary institutions that have similar facilities and majors, (2) the product of development is not only in badminton science subjects, but also in all courses that are presented in the Department of Physical Education Health and Recreation at Universitas Islam Riau.

The limitation of this study is that it only addresses one University in Riau Province and the number of students subjected to trials is too small for research. It is expected that other researchers can continue this research with a large number of test subjects so that the obtained data is more accurate.

\section{Acknowledgements}

The researcher would like to thank several parties who have supported in completing this research.

1. Institute for Research and Community Service (LPPM) Universitas Islam Riau

2. Dean of the Teaching and Education Faculty Universitas Islam Riau

3. Head of the Department of Physical Education Health and Recreation 


\section{REFERENCES}

[1] Abidin, Y. (2014). Desain Sistem Pembelajaran Dalam Konteks Kurikulum 2013. Bandung, Indonesia: Refika Aditama.

[2] Azwar, S. (2012). Reliabilitas dan Validitas. Yogyakarta: Pustaka Pelajar.

[3] Borg, W. R. \& Gall, M. D. (1983). Educational Research An Introduction. New York: Longman.

[4] BSNP. (2014). Instrumen Penilaian Buku Teks Pelajaran Pendidikan Dasar dan Menengah. Jakarta: BSNP.

[5] Budiningsih, T. Y., Rusilowati, A., \& Marwoto, P. (2015). Pengembangan Buku Ajar IPA Terpadu Berorientasi Literasi Sains Materi Energi dan Suhu. Journal of Innovative Science Education, 4(2). 34-40.

[6] Chval, K., Heck, D., Weiss, I. \& Ziebarth, S.W. (2012). Approaches to studying the enacted mathematics curriculum. A volume in the series Research in Mathematics Education. Charlotte: Information Age Publishing.

[7] DePoy, E., \& Gitlin, L. (2016). Introduction to Research: Understanding and Applying Multiple Strategies (5th ed.). London: Mosby. https://doi.org/10.1016/B978-0-323-26171-5.00017-3.

[8] Fidiastuti, H. R. \& Rozana, K. M. (2016). Developing Modul of Microbiology Subject Through Biodegradation by Using The Potencial of Indigen Bacteria. Jurnal Pendidikan Biologi Indonesia, 2(2), 125-132.

[9] Husamah., Rochman, F.,\&Sutomo, H. (2016). Development of Enrichment Book of Animal Ecology Based on Collembola Community Structure Research Throughout Watershed Brantas Upstream of Batu City.Research Report.

[10] Lufthansa, L., Susilo, S., Zaini, M., Kusmawati, W., Pawitra, P. R. A., \& Anugraini, A. P. (2019). Pengembangan Buku Ajar Ilmu Gizi Olahraga: Studi Motivasi dan Hasil Belajar. Journal Sport Area, 4(2), 327-338

[11] Mohajan, H. K. (2017). Two Criteria for Good Measurements in Research: Validity and Reliability. Annals of Spiru Haret University, 17(3), 58-82.

[12] Polikoff, M. S. (2015). How well aligned are textbooks to the common core standards in mathematics? U. S. Educational Research Journal, 52(6), 1185-1211. https://doi.org/10.3102/00028 31215584435.

[13] Prastowo, A. (2011). Panduan kreatif membuat bahan ajar inovatif. Yogyakarta: DIVA Press.

[14] Rahmantiwi, W. B, (2012). Pengembangan Bahan Ajar Matematika Berbentuk Modul Pada Materi Himpunan Dengan Pendekatan Matematika Ralistik Indonesia (PMRI) Untuk Meningkatkan Hasil Belajar Siswa SMP Kelas VII Semester Genap. Thesis, Yogyakarta: Program Studi Pendidikan Matematika, Fakultas Matematikadan Ilmu Pengetahuan Alam. UNY.

[15] Rezat, S. (2012). Interactions of teachers' and students' use of mathematics textbooks. In G. Gueudet, B. Pepin, \& L. 